\title{
A new species of Parotocinclus with reduced adipose fin (Loricariidae: Hypoptopomatinae), from the rio Jacuípe basin, Bahia State, Brazil
}

Correspondence:

Angela Maria Zanata zanata.angela@gmail.com

Submitted December 23, 2019

Accepted March 30, 2020

by Priscila Camelier

Epub Jun 17, 2020

\section{${ }^{\oplus}$ Dario Ernesto da Silva-Junior ${ }^{1},{ }^{\oplus}$ Telton Pedro Anselmo Ramos ${ }^{2}$ and ${ }^{\bullet}$ Angela Maria Zanata ${ }^{1}$}

A new species of Parotocinclus, apparently endemic to the rio Jacuípe basin, Bahia State, Brazil, is described. The new species is distinguished from congeners, except P. bidentatus, P. cabessadecuia, P. dani, P. halbothi, P. muriaensis, P. pentakelis, P. seridoensis, and P. spilurus, by the presence of a reduced adipose fin. The new species differs from the aforementioned species by the absence of unicuspid accessory teeth, abdomen with broad naked areas between lateral and medial patches of plates, and snout tip completely covered by plates and odontodes. The adipose fin of the new species is restrict solely to the adipose-fin spine, lacking the adipose-fin membrane, a reduction pattern previously described to P. halbothi, a congener from rivers of the Amazonas and Marowijne basins.

Keywords: Cascudinho, Catfishes, Northeastern Mata Atlântica freshwater ecoregion, Siluriformes, Taxonomy.
Online version ISSN 1982-0224

Print version ISSN 1679-6225

Neotrop. Ichthyol.

vol. 18, no. 2, Maringá 2020
1 Programa de Pós-Graduação em Biodiversidade e Evolução, Instituto de Biologia, Universidade Federal da Bahia, Rua Barão de Jeremoabo, 147, Ondina, 40170-115 Salvador, BA, Brazil. (DESJ) dariolabufs@gmail.com; (AMZ) zanata.angela@gmail.com (corresponding author).

2 Laboratório de Ecologia Aquática, Universidade Estadual da Paraíba, Departamento de Biologia/CCBS, Campus Universitário, 58109-753 Campina Grande, PB, Brazil. (TPAR) telton@gmail.com. 
Uma espécie nova de Parotocinclus, aparentemente endêmica da bacia do rio Jacuípe, Estado da Bahia, Brasil, é descrita. A espécie nova se distingue de suas congêneres, exceto $P$. bidentatus, $P$. cabessadecuia, $P$. dani, $P$. halbothi, $P$. muriaensis, P. pentakelis, $P$. seridoensis e $P$. spilurus, pela presença de nadadeira adiposa reduzida. A nova espécie difere das espécies mencionadas anteriormente pela ausência de dentição acessória unicúspide, abdômen com amplas áreas nuas entre o grupo de placas laterais e o grupo de placas medianas e ponta do focinho completamente coberta por placas e odontódeos. A nadadeira adiposa da nova espécie é restrita somente ao espinho, sem a membrana da adiposa, um padrão de redução descrito para $P$. halbothi, uma congênere de rios da bacia Amazônica e da bacia do rio Marowijne.

Palavras-chave: Bagre, Cascudinho, Ecorregião Mata Atlântica Nordeste, Siluriformes, Taxonomia.

\section{INTRODUCTION}

The absence or reduction of morphological body features has been reported in various genera of Siluriformes (e.g., Fisch-Muller et al., 2005; Datovo, 2014; Fernández et al., 2014), usually related to specific life habits such as the occupation of caves and subterranean water bodies (Fernández, Bichuette, 2002; Secutti, Trajano, 2009; Datovo, 2014). In such cases, morphological losses would be a consequence of troglomorphism that happens in taxa independently of phylogenetic relationship (Mattox et al., 2008). However, epigean species of Siluriformes also present structural reductions, noticed primarily among armored catfishes by reduced or fused bones, decrease of dermal plates' size and number, and rudimentary fins (e.g., Britto, Moreira, 2002; Armbruster, Taphorn, 2011; Covain et al., 2016).

Although recorded for various members of the Loricariidae, reduction is more frequently associated to small-sized representatives, with remarkable reduction of dermal plates, bones, and fins in species of the Hypoptopomatinae (Ribeiro et al., 2005; Carvalho et al., 2008; Rosa et al., 2014). Particularly in species of Parotocinclus Eigenmann \& Eigenmann, such modifications are exemplified by reduction or fusion of bones and incomplete longitudinal series of dermal plates (e.g., Gauger, Buckup, 2005; Lehmann et al., 2018) and rudimentary structures such as vestigial adipose fin (e.g., Lehmann et al., 2014; Roxo et al., 2016; Ramos et al., 2017).

Parotocinclus is recognized essentially by the presence of a well-developed adipose fin, but eight out of the 34 valid species of the genus have been described with vestigial or rudimentary adipose fin. Among those species, P. dani Roxo, Silva \& Oliveira from the rio Tapajós basin, P. halbothi Lehmann, Lazzarotto \& Reis from Amazonas and Marrowijne basins, and P. pentakelis Roxo, Messias \& Silva from the rio Tocantins basin share exclusively the possession of a dark blotch at the anterior portion of dorsal-fin membrane, five transverse dark bars along body, and the canal cheek plate on the ventral surface of head elongated posteriorly and contacting the cleithrum 
(Schmidt, Ferraris, 1985; Lehmann et al., 2014; Roxo et al., 2016; Roxo et al., 2019). The other five species of Parotocinclus with reduced or rudimentary adipose fin are distributed along rivers draining the eastern coast of Brazil, within distinct freshwater ecoregions (sensu Abell et al., 2008): P. cabessadecuia Ramos, Lima, Ramos from the Parnaíba freshwater ecoregion, P. seridoensis Ramos, Barros-Neto, Britski, Lima and P. spilurus (Fowler), the latter with an occasional reduction of adipose fin, from both Northeastern Caatinga and Coastal Drainages ecoregions, and P. bidentatus Gauger, Buckup and P. muriaensis Gauger, Buckup both from the Paraiba do Sul ecoregion.

Herein, the first species of Parotocinclus with a reduced adipose fin occurring in the Northeastern Mata Atlântica Freshwater ecoregion (NMAF) is described. The species is apparently endemic to the rio Jacuípe basin, a small independent coastal drainage of Bahia State.

\section{MATERIAL AND METHODS}

Methods, osteological terminology, and counts follow Boeseman (1968) and Schaefer $(1987,1997)$. The conditions cited in the text associated to different degrees of development of the adipose fin in Parotocinclus are: 1) adipose fin completely developed means presence of a well developed spine and membrane connecting the spine to the body; 2) adipose fin reduced means presence of a well developed spine but absence of the membrane; 3 ) adipose fin rudimentary means spine and membrane absent but presence of a ridge visible externally along the adipose-fin typical locality and examination of cleared and stained specimens reveals the ridge formed by a series of unpaired plates covered by odontodes; and 4) adipose fin vestigial means spine, membrane or ridge absent and a single platelet located in the adipose-fin typical locality. Standard length (SL) is expressed in millimeters and all other measurements as percents of SL or of head length (HL).

Measurementswere taken aspoint-to-pointlinear distances under an estereomicroscope, using digital calipers to the nearest $0.1 \mathrm{~mm}$ on the left side of the specimens whenever possible. Specimens were cleared and stained (c\&s) for observation of bones and cartilage according to Taylor, Van Dyke (1985). Vertebral counts include the five vertebrae of the Weberian apparatus and the compound caudal centrum, counted as a single element.

List of examined specimens includes the total number and size range of the specimens, followed by the number and size range of the measured specimens given in parentheses, if different. Examined specimens are preserved in alcohol, except when indicated as c\&s. Institutional abbreviations follow Fricke, Eschmeyer (2020). Comparisons with species not listed in the Comparative material examined section were based on the literature data (i.e., Boeseman, 1974; Schmidt, Ferraris Jr, 1985; Schaefer, 1988; Schaefer, Provenzano, 1993; Gauger, Buckup, 2005; Lehmann, Reis, 2012; Lehmann et al., 2015; Roxo et al., 2016; Roxo et al., 2017; Lehmann et al., 2018; Pereira et al., 2019; Roxo et al., 2019). 
Parotocinclus jacumirim, new species

urn:lsid:zoobank.org:act:9748E789-B3C4-48BC-8FF9-E888370C4C9D

(Figs. 1-2; Tab. 1)

Holotype. MZUSP 125761, 34.5 mm SL, Brazil, Bahia State, Dias d’Ávila, rio Jacumirim, tributary of rio Jacuípe, on road BA-093 between municipalities of Dias d'Ávila and Mata de São João, 12³4’59.3”S 38¹8’59.6”W, 5 Apr 2019, A. M. Zanata, P. C. Camelier, L. O. Silva \& V. P. Abrahão.

Paratypes. All specimens from type locality. MZUSP 125762, 2, 29.4-33.2 mm SL, UFBA 8924, 11, 22.7-39.9 mm SL + 7 tissue samples, collected with holotype. UFBA 7562, 25, 36.8-47.5 mm SL, 2 c\&s, 29.7-30.9 mm SL, 21 Apr 2013, A. M. Zanata, T. Ramos, L. Oliveira \& T. Duarte. MCP 54426, 3, 28.6-37.3 mm SL; UFBA 7600, 22, 39.9-50.7 mm SL; UFPB 11971, 3, 32.3-33.6 mm SL, 5 Nov 2005, C. Figueiredo, A. M. Zanata. UFPB 12003, 3, 28.8-34.8 mm SL, 5 Jun 2013, C. Figueiredo, A. M. Zanata.

Diagnosis. Parotocinclus jacumirim is distinguished from its congeners, except $P$. bidentatus, P. cabessadecuia, P. dani, P. halbothi, P. muriaensis, P. pentakelis, P. seridoensis, and P. spilurus, by the possession of a reduced adipose fin, restricted to the adipose-fin spine (vs. adipose fin completely developed). The new species differs from P. bidentatus, $P$. halbothi, and P. muriaensis by lacking unicuspid accessory teeth (vs. unicuspid accessory teeth present), from P. bidentatus, P. cabessadecuia, P. dani, P. muriaensis, P. pentakelis, and $P$. spilurus by possessing broad naked abdominal areas between lateral and medial patches of plates ( $v s$. abdomen without broad naked areas, covered by small or large platelets); and from P. seridoensis by having the snout tip completely covered by plates and odontodes ( $v s$. naked area at snout tip).

Description. Standard length of examined specimens 24.0-50.7 mm SL. Measurements and counts in Tab. 1. Body elongate, without conspicuous keels, moderately depressed. Trunk trapezoidal, and caudal peduncle ellipsoid in cross section. Dorsal profile of body slightly convex from snout tip to supraoccipital process and slightly convex to straight from that point to dorsal-fin origin. Dorsal profile straight from dorsal-fin origin to caudal-peduncle midlength and somewhat concave from that point to origin of dorsalmost caudal-fin rays. Greatest body width at cleithrum, progressively tapering posteriorly, and greatest body depth at dorsalfin origin, gradually tapering posteriorly to caudal peduncle. Ventral profile slightly concave from snout tip to cleithrum, straight to slightly convex from that point to anus, slightly slanted from anus to end of anal-fin base, almost straight along caudal peduncle.

Head rounded anteriorly in dorsal view. Interorbital region flat to slightly convex with supraorbital margins elevated. Snout elongate, depressed. Nostrils ovoid and positioned closer to anterior margin of orbit than from snout tip. Internareal area slightly elevated. Eye medium-sized, dorsolaterally positioned. Patch of slightly 


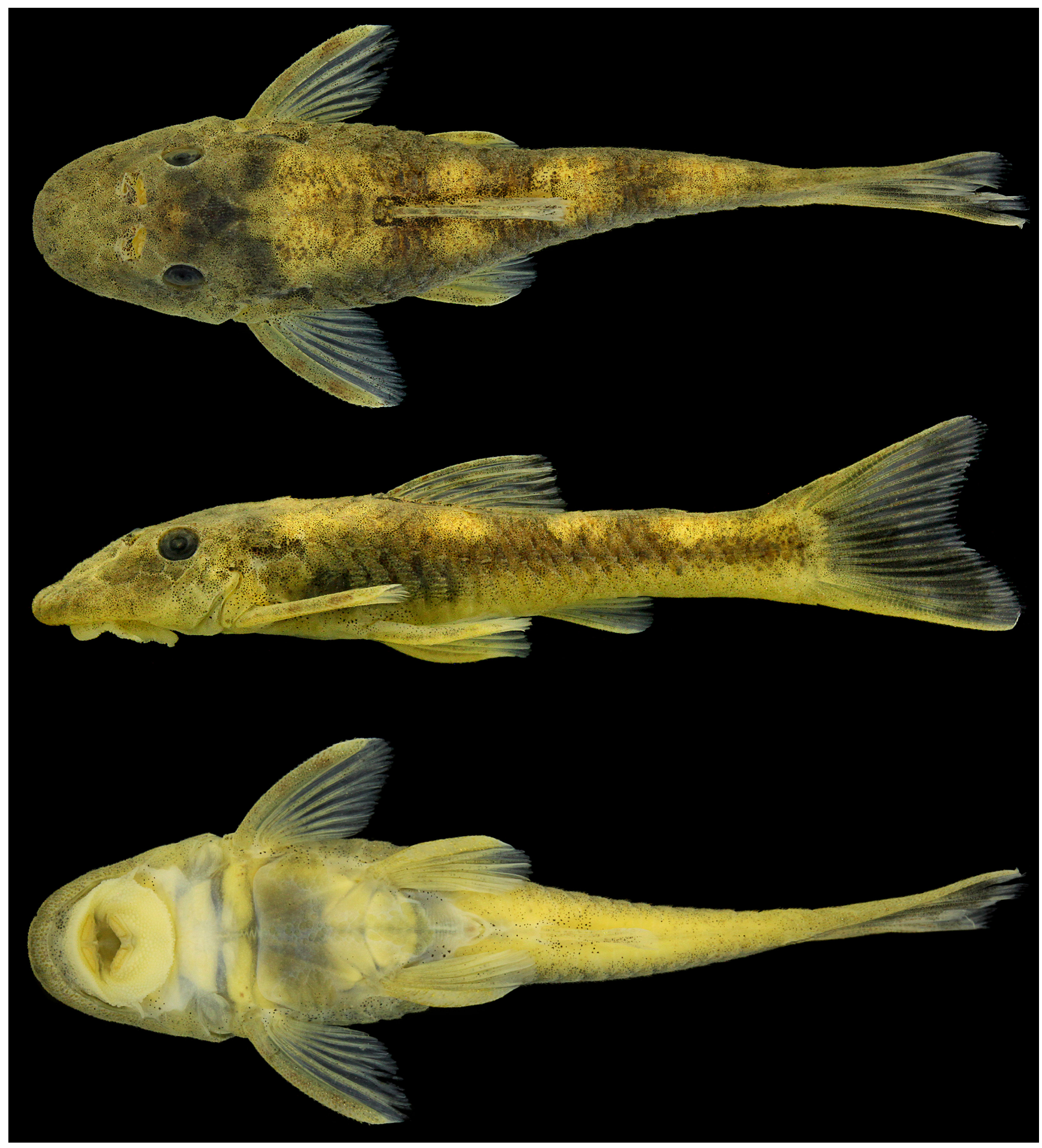

FIGURE 1 I Parotocinclus jacumirim, holotype, MZUSP 125761, female, 34.5 mm SL, rio Jacumirim, tributary of rio Jacuípe, on road BA-093 between municipalities of Dias d'Ávila and Mata de São João, Dias d'Ávila, Bahia, Brazil. 
TABLE 1 I Morphometric and meristic data of Parotocinclus jacumirim $(\mathrm{n}=35)$. Ranges include holotype. $\mathrm{SD}=$ standard deviation

\begin{tabular}{|c|c|c|c|c|c|}
\hline & Holotype & Min & $\operatorname{Max}$ & Mean & SD \\
\hline Standard length (in $\mathrm{mm}$ ) & 34.5 & 24.0 & 50.7 & 32.8 & - \\
\hline \multicolumn{6}{|l|}{ Percent of standard length } \\
\hline Head length & 36.5 & 34.2 & 40.8 & 36.1 & 1.2 \\
\hline Predorsal distance & 47.3 & 40.4 & 48.8 & 46.5 & 1.0 \\
\hline Pre-anal distance & 64.4 & 62.2 & 65.8 & 64.1 & 1.0 \\
\hline Pectoral-pelvic distance & 16.0 & 14.7 & 18.0 & 16.7 & 0.9 \\
\hline Abdominal length & 19.9 & 17.6 & 23.0 & 20.8 & 1.2 \\
\hline Caudal peduncle depth & 10.3 & 9.6 & 12.0 & 10.9 & 0.6 \\
\hline Dorsal-fin spine length & 21.9 & 19.1 & 23.0 & 21.2 & 1.0 \\
\hline Anal-fin spine length & 14.0 & 12.4 & 15.8 & 14.2 & 0.9 \\
\hline Pectoral-fin spine length & 22.8 & 18.1 & 23.3 & 21.5 & 1.0 \\
\hline Pelvic-fin spine length & 17.9 & 15.2 & 20.3 & 18.0 & 1.1 \\
\hline Body depth at dorsal origin & 18.5 & 16.3 & 20.1 & 17.6 & 1.0 \\
\hline Cleithral width & 25.6 & 23.9 & 27.1 & 25.5 & 0.8 \\
\hline \multicolumn{6}{|l|}{ Percent of head length } \\
\hline Head depth & 45.2 & 42.8 & 47.5 & 45.1 & 1.1 \\
\hline Snout length & 55.6 & 50.9 & 57.1 & 55.0 & 1.3 \\
\hline Snout-opercle length & 73.8 & 71.1 & 75.7 & 73.4 & 1.2 \\
\hline Orbital diameter & 14.3 & 13.7 & 18.3 & 15.6 & 1.1 \\
\hline Interorbital width & 34.9 & 31.6 & 38.5 & 35.9 & 1.2 \\
\hline Counts & & & & Mode & \\
\hline Right premaxillary teeth & 22 & 20 & 25 & 23 & \\
\hline Left premaxillary teeth & 20 & 20 & 26 & 23 & \\
\hline Right dentary teeth & 21 & 20 & 26 & 22 & \\
\hline Left dentary teeth & 20 & 20 & 25 & 23 & \\
\hline Predorsal series of plates & 3 & 3 & 4 & 3 & \\
\hline Plates below dorsal-fin base & 5 & 5 & 5 & 5 & \\
\hline Dorsal plates between dorsal fin and adipose spine & 12 & 10 & 12 & 11 & \\
\hline Dorsal series of plates & 20 & 18 & 21 & 19 & \\
\hline Mid-dorsal series of plates & 17 & 17 & 19 & 18 & \\
\hline Median series of plates & 22 & 22 & 24 & 23 & \\
\hline Mid-ventral series of plates & 18 & 17 & 19 & 18 & \\
\hline Ventral series of plates & 17 & 17 & 20 & 17 & \\
\hline Ventral plates between anal and caudal fins & 10 & 10 & 11 & 10 & \\
\hline Branched pectoral-fin rays & 6 & 6 & 6 & 6 & \\
\hline Branched dorsal-fin rays & 7 & 7 & 7 & 7 & \\
\hline Branched pelvic-fin rays & 5 & 5 & 5 & 5 & \\
\hline Branched anal-fin rays & 5 & 5 & 5 & 5 & \\
\hline Branched caudal-fin rays & 14 & 14 & 14 & 14 & \\
\hline
\end{tabular}


hypertrophied odontodes at posterior tip of supraoccipital bone. Odontodes on head equal in size to those on trunk, but border of snout tip with somewhat larger and curved odontodes. Mouth wide and lips rounded; lower lip with delicate fringed margin and not reaching transverse line between gill openings. Lips covered by papillae, except for region immediately behind dentary teeth; papillae of upper lip rounded and small; anteriormost papillae of lower lip digitiform and large, decreasing in size towards lower-lip margin. Teeth slender and bicuspid. Blade-like medial cusp inward curved and approximately three times longer than pointed lateral cusp. Accessory unicuspid teeth absent.

Body entirely covered by dermal plates, except for naked areas around lips, nares, paired-fin bases, parts of abdomen, and anus. Trunk covered by five longitudinal series of dermal plates. Somewhat aligned odontodes covering most of lateral plates, forming parallel to somewhat divergent rows; rows usually more conspicuous on posterior half of body; odontodes slightly larger on posterior border of plates. Median series of lateral plates bearing complete and uninterrupted lateral-line canals. Pored tubes of lateral line visible from compound pterotic to penultimate plate. Trunk plates without keels. Pectoral girdle partially exposed, with anterior medial portion covered by skin. Arrector fossae large and medially positioned. Laterals of abdomen with patch of plates, positioned between coracoid and pelvic fins, isolated from median abdominal plates by broad naked areas; some large specimens (larger than $35 \mathrm{~mm} \mathrm{SL}$ ) with lateral and median patch of plates somewhat connected by a few small plates but with broad naked areas anteriorly and posteriorly to the connection. Lateral patches oval and formed by large laterally elongate plates. Median patch pointed anteriorly close to coracoid and somewhat enlarged and rounded posteriorly, reaching area beyond pelvic-fin base; posteriormost plates usually larger than anterior most plates.

Dorsal-fin rays I,7, spine somewhat arched. Dorsal-fin origin slightly posterior to vertical through pelvic-fin origin. Dorsal-fin spinelet present, plate-like and slightly v-shaped, articulated to first dorsal-fin pterygiophore. Pectoral-fin rays I,6. Pectoral fin with large spine slightly arched; tip of adpressed spine reaching between proximal third to half of pelvic-fin length. Pelvic-fin rays i,5; tip of adpressed fin reaching to anal-fin origin in males, shorter in females. Adipose-fin reduced to poorly visible elevation situated at typical adipose-fin position and adipose-fin membrane absent (type 2 described in the Material and Methods); slightly arched adipose-fin spine visible in c\&s specimens, similar in size compared to congeners with adipose fin completely developed; adipose-fin spine not merged to caudal peduncle but juxtaposed to it. Anal-fin rays i,5. Caudal-fin rays i,14,i, with lower unbranched ray slightly longer than upper. Vertebral centra 27 (1), 28 (1), and seven pleural ribs (2).

Coloration in alcohol. Overall ground color of dorsal and lateral surface of head and trunk pale yellow or light brown (Fig. 1). Black chromatophores sparsely distributed on head and body, rarely on belly; brown chromatophores more rarely distributed between black chromatophores. Dorsal surface of head from interorbital to posterior end of supraoccipital darker than snout. Snout usually with black chromatophores homogeneously distributed; some small specimens (up to $30 \mathrm{~mm}$ SL) with chromatophores forming distinctly dark patches isolated from each other by clearer areas; dark patches on laterals of head of such specimens forming rough 
dark narrow stripe from tip of snout to opercle. Dark broad midlateral stripe from rear of opercle to end of caudal peduncle; dorsal and ventral borders of stripe inconspicuous in some specimens; dorsal margin merged with dark vertical bars. Four transverse dark bars crossing dorsal half of body; first bar situated on anterior portion of dorsal-fin base, second aligned to final third of dorsal-fin rays, third aligned to distal half of anal-fin rays, and fourth positioned just ahead of caudal-fin origin. Rays of dorsal, anal, pectoral, and pelvic fins with alternation of dark and clearer bands formed by concentration of black and brown chromatophores, respectively; bands less evident on unbranched rays; interradial membranes hyaline, except on caudal fin. Caudal fin with black and brown blotches, not forming bands; black blotches mainly concentrated on lower lobe and formed by pigmentation of portions of rays and interradial membranes. Ventral surface pale yellow, with black chromatophores sparsely distributed on borders of head, laterals of body, and posterior to anus.

Color in life. Pattern of dark bars and stripes in freshly collected specimens similar to preserved specimens, although somewhat less evident, and clear brown background color (Fig. 2)

Sexual dimorphism. Mature males of Parotocinclus jacumirim have urogenital papilla positioned immediately posterior to the anal opening, a structure absent in females. Males also differ from females by having longer pelvic fin, with tip of first unbranched ray ending posteriorly to the anal-fin origin, and by the presence of a skin flap along the dorsal portion of the first unbranched pelvic-fin ray. In females, the pelvic fin ends anteriorly or close to the anal-fin origin and there is no skin flap on the first pelvic-fin ray. Additionally, males of P. jacumirim have the posterior nostril aperture approximately two times broader than females.

Geographical distribution. The new species is known from the rio Jacumirim, a tributary of the rio Jacuípe, a relatively small independent drainage situated in Bahia State, with headwaters between municipalities of Conceição do Jacuípe and Amélia Rodrigues, and emptying directly in the Atlantic Ocean (Fig. 3).

Ecological notes. The rio Jacumirim is within the geographical Atlantic Forest domain, in area once dominated by Atlantic Forest but currently altered by anthropic

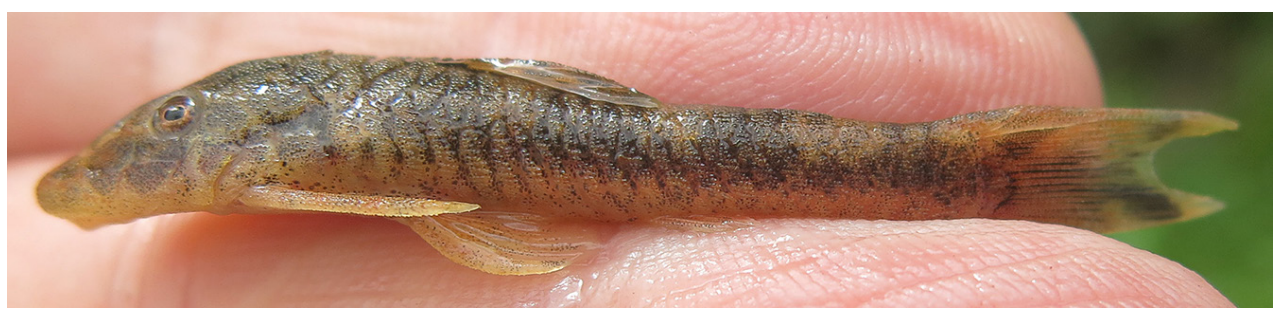

FIGURE 2 I Parotocinclus jacumirim, live paratype, UFBA 8924, not measured, rio Jacumirim, tributary of rio Jacuípe, on road BA-093 between municipalities of Dias d'Ávila and Mata de São João, Dias d'Ávila, Bahia, Brazil. 


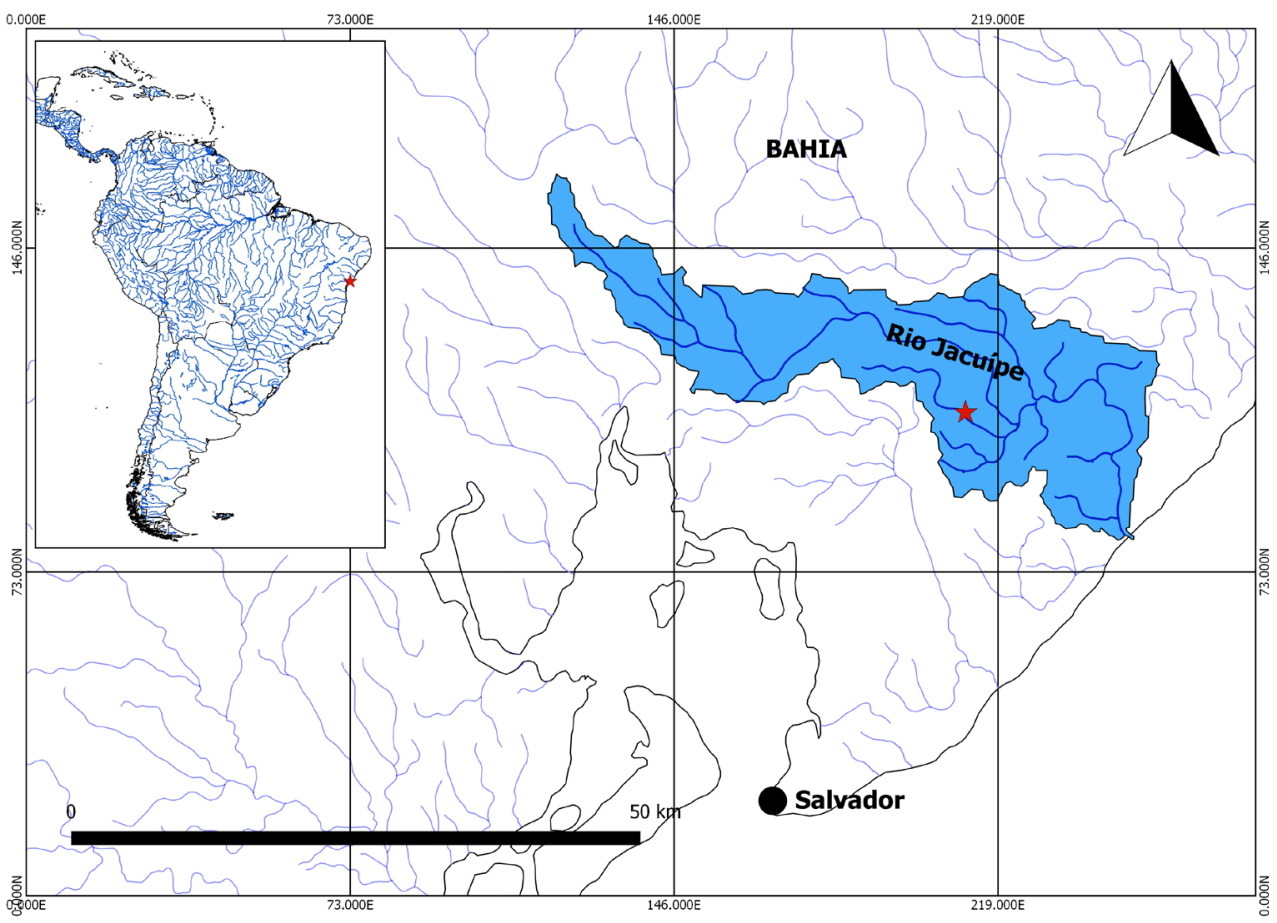

FIGURE 3 I Distribution of Parotocinclus jacumirim (red star), rio Jacumirim, tributary of rio Jacuípe, on road BA-093 between municipalities of Dias d'Ávila and Mata de São João, Dias d'Ávila, Bahia, Brazil.

actions. The sampled river stretch is approximately one meter wide, varying from a few centimeters up to one meter deep, characterized by having fast water flow, substrate formed mainly by peebles, sand and organic debris, and marginal vegetation with dense grass bushes, sparse trees, and palm trees (Fig. 4). Parotocinclus jacumirim was collected syntopically with Atyanax aff. fasciatus Cuvier, Poecilia reticulata Peters, and a species of Rhamdia Bleeker.

Etymology. Named after the rio Jacumirim, the type locality and the only river where the species is known up to date. The specific name, jacumirim, from the Tupi indigenous language "Jacu" from "Jacuípe", meaning the river of jacús, a species of bird, and "mirim", meaning small. A noun in apposition.

Conservation status. Up to date, Parotocinclus jacumirim possesses a relatively small known distribution, collected at just one locality of the rio Jacuípe basin. The area drained by the basin is anthropically altered and the collecting site is within an industrial region of Bahia, in the surroundings of the Pólo Industrial de Camaçari. However, no adequate information is available to make direct, or indirect, assessments of extinction risk based on the distribution and/or population status of the species. Therefore, P. jacumirim could be classified as Least Concern (LC), according to the International Union for Conservation of Nature Standards and Petitions Committee (IUCN, 2019). 


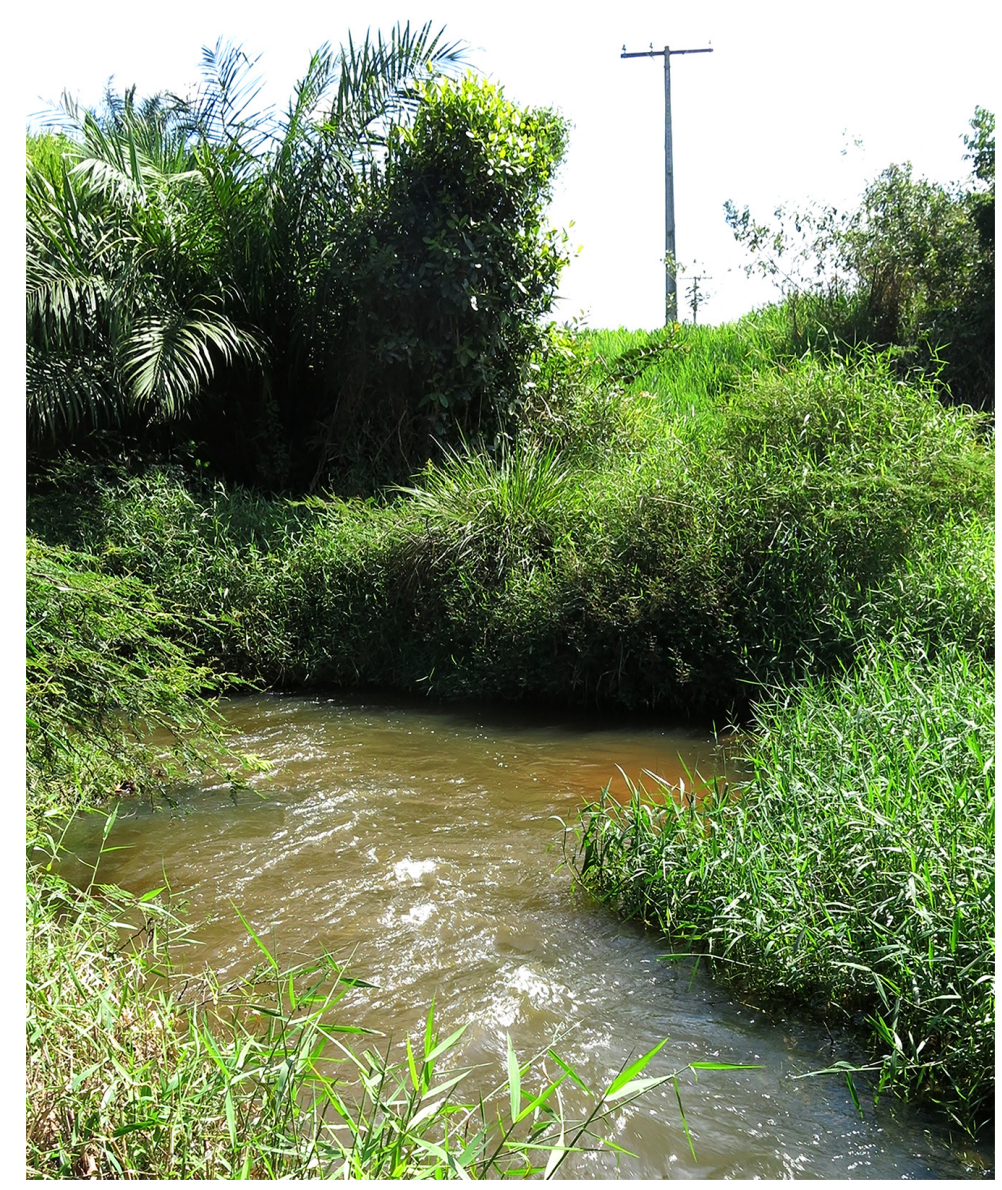

FIGURE 4 I Type locality of Parotocinclus jacumirim, rio Jacumirim, tributary of rio Jacuípe, on road BA093 between municipalities of Dias d'Ávila and Mata de São João, Dias d'Ávila, Bahia, Brazil.

\section{DISCUSSION}

Although traditionally recognized by the presence of a developed adipose fin, Parotocinclus includes eight species, described mainly in the last decade, diagnosed by the absence or reduction of such a fin (i.e., P. bidentatus, P. cabessadecuia, P. dani, P. halbothi, P. muriaensis, P. pentakelis, P. seridoensis and, occasionally, P. spilurus). At least three conditions of adipose-fin reduction are known to species of Parotocinclus: 1) adipose fin reduced, with spine but without membrane connecting the spine to the body, described to P. halbothi by Lehmann et al. (2014) and similar to the condition observed herein to P. cabessadecuia (UFPB 11011, 2 c\&s, 26.4-27.3 mm SL) and P. seridoensis (UFRN 0005, 2 c\&s, 29.8-37.0 mm SL); 2) adipose fin rudimentary, without spine and membrane, only represented by a ridge, originally described to P. spilurus by Fowler (1941) and apparently similar to the condition observed in $P$. bidentatus and P. muriaensis (Gauger, Buckup, 2005); and 3) adipose fin vestigial, with a small platelet at the typical adipose-fin location, described to P. pentakelis by Roxo et al. (2019) and P. dani (Roxo et al., 2016). Parotocinclus jacumirim possesses a well 
developed adipose-fin spine, similar in size to congeners that possess a well-developed adipose fin, but the membrane in the new species is absent and the spine is juxtaposed to the body. The condition of the adipose fin of P. jacumirim is similar to that found in P. cabessadecuia, P. halbothi, and P. seridoensis. A detailed description of the reductions present in other species of Parotocinclus is unavailable and a better evaluation of the conditions occurring in the genus is desirable.

Adipose-fin origin, evolution, morphology, and function have been discussed and most authors use words as "enigmatic", "challenge", "cryptic", "poorly understood" or "highly homoplastic" to the structure (e.g., Garstang, 1931; Reimchen, Temple, 2004, Temple, Reimchen, 2008; Bender, Moritz, 2013; Stewart, Hale, 2013; Stewart et al., 2014). Particularly to Siluriformes, a few studies of the adipose fin are available, focused on the origin and evolutionary history (e.g., Sandon, 1956; Stewart et al., 2014), morphology (e.g., Stewart, Hale, 2013), or function (e.g., Temple, Reimchen, 2008). Temple, Reimchen (2008) suggested significant association of species possessing adipose fin as predominantly living in flowing environments, while species lacking the adipose fin frequently living in no-flow or slow-flow environments. Loricariidae is considered as having adipose "sometimes present" by these authors, and their results indicate a positive association of presence of adipose fin with moderate to rapid water flow in the family. In fact, a number of loricariid genera, from different subfamilies, is diagnosed by the absence of an adipose fin (e.g., most hypoptopomatines, all loricariines), and in a few genera the occurrence of the fin is variable (e.g., Hypoptopoma Günther, Pareiorhaphis Miranda Ribeiro, Schizolecis Britski, Garavello, Parotocinclus). Particularly, members of the subfamily Hypoptopomatinae occupied both slow-flowing/vegetated habitat and rapids habitats with fast-flowing water and rocky substrate approximately at 58.4 million years ago, with its tribes Hypoptopomatini and Otothyrini remaining largely restricted to similar habitats up to date (Roxo et al., 2016). Thus, an association of absence of adipose fin and no-flow or slow-flow environments as proposed by Temple, Reimchen (2008) is apparently not strictly valid for hypoptopomatins. In accordance, the adipose-fin reduced species P. cabessadecuia, P. jacumirim, and P. halbothi were sampled solely in fast-flowing water flow (Lehmann et al., 2014; Ramos et al., 2017; present study), and P. seridoensis in moderate water flow environments (Ramos et al., 2013). Information about habitat preferences of other congeners with reduced adipose fin is not available.

Comparative material examined. All from Brazil: Parotocinclus arandai: MNRJ 28296, holotype, 37.7 mm SL; Minas Gerais, Córrego Bananeiras. Parotocinclus bahiensis: MZUSP 99753, neotype, 30.3 mm SL; UFBA 2890, 38, 16.0-27.3 mm SL; Bahia, rio Itapicuru basin. Parotocinclus cabessadecuia: UFPB 10029, holotype, 29.3 mm SL; Piauí, rio Parnaíba basin. Parotocinclus cearensis: MNRJ 8689, paratypes, 10, 20.6-24.2 mm SL; Ceará, rio Acaraú basin. Parotocinclus cesarpintoi: MNRJ 1022, syntypes, 10, 34.6-41.6 mm SL; Alagoas, rio Parnaíba do Meio basin. Parotocinclus cristatus: MNRJ 10128, paraype, $25.3 \mathrm{~mm} \mathrm{SL}$; MNRJ 10131, paratype, $27.5 \mathrm{~mm}$ SL; Bahia, rio Almada basin. Parotocinclus doceanus: MZUSP 1016, holotype, $31.2 \mathrm{~mm}$ SL; Espírito Santo, rio Doce basin. Parotocinclus haroldoi: MNRJ 10531, holotype, 35.8 mm SL; MNRJ 10532, paratype, $35.2 \mathrm{~mm}$ SL; MNRJ 10533, paratype, $31.6 \mathrm{~mm}$ SL; Piauí, rio Riacho Sanharó basin. Parotocinclus jequi: MZUEL 7350, 5, 31.6-42.8 
mm SL; MZUEL 7368, 5, 27.2-50.5 mm SL; Minas Gerais, rio Jequitinhonha basin. Parotocinclus jimi: MZUSP 12154, paratype, $34.3 \mathrm{~mm}$ SL; Bahia, rio de Contas basin; UFBA 3848, 12, 23.9-29.3 mm SL; Bahia, rio de Contas basin. Parotocinclus jumbo: MZUSP 69513, holotype, 43.0 mm SL; Paraíba, rio Paraíba do Norte basin; UFBA 3815, 5, 22.8-34.1 mm SL; Pernambuco, rio Ipojuca basin. Parotocinclus longirostris: MZUSP 36891, holotype, $27.8 \mathrm{~mm}$ SL; Amazonas, rio Amazonas basin. Parotocinclus maculicauda: UFBA 6504, 3, 33.3-35.0 mm SL; Espírito Santo, rio Doce basin. UFRN 1010, 10, 23.0-33.7 mm SL; Rio de Janeiro, rio São João basin. Parotocinclus minutus: UFBA 3645, 5, 23.2-24.9 mm SL; UFBA 3644, 5, 26.3-32.2 mm SL; Bahia, rio VazaBarris basin. Parotocinclus planicauda: MZUSP 75071, holotype, $34.2 \mathrm{~mm}$ SL; Minas Gerais, rio Suaçui Pequeno basin. Parotocinclus prata: MZUSP 68359, holotype, 38.2 mm SL; Minas Gerais, rio São Francisco basin. Parotocinclus seridoensis: UFPB 9218, 5, 28.1-39.7 mm SL; Rio Grande do Norte, rio Piranhas-Açu basin. Parotocinclus spilosoma: UFRN 0698, 19, (1 c\&s), 19.6-40.4 mm SL; Paraíba, rio Paraíba do Norte basin. Parotocinclus spilurus: ANSP 69403, holotype, 28.6 mm SL; ANSP 69404, paratypes, 5, (1 c\&s), 24.4-28.4 mm SL; UFPB 9012, topotypes, 9, 17.7-31.3 mm SL; Ceará, rio Jaguaribe basin.

\section{ACKNOWLEDGMENTS}

For the loan or permission to examine comparative material we thank L. Ingenito (INMA), O. T. Oyakawa (MZUSP), and Robson Tamar (UFPB). We also thank C. Figueiredo, L. O. Silva, L. A. Oliveira, P. Camelier, R. Burger, T. Duarte, and V. Abrahão for help in fieldwork and R. Abreu for the photographs. Funding for field work in which the new species also was collected was provided by $\mathrm{CNPq}$ (grant \# 476495/2010-5; \# 562335/2010-2). This study was financed in part by the Coordenação de Aperfeiçoamento de Pessoal de Nível Superior - Brasil (CAPES)

- Finance Code 001. AMZ is partially financed by the Conselho Nacional de Desenvolvimento Científico e Tecnológico (CNPq process \# 309993/2016-4). DES-J is financed by CAPES/CNPQ - PROTAX II process \# 88887.1850/2018-00. Permission for collecting specimens was granted by ICMBio \# 13754-1.

\section{REFERENCES}

- Abell R, Thieme ML, Revenga C, Bryer M, Kottelat M, Bogutskaya N et al. Freshwater Ecoregions of the World: A New Map of Biogeographic Units for Freshwater Biodiversity Conservation. BioScience. 2008; 58(5):403-14. https://doi. org/10.1641/B580507

- Armbruster JW, Taphorn DC. A new genus and species of weakly armored catfish from the upper Mazaruni River, Guyana (Siluriformes: Loricariidae). Copeia. 2011; 2011(1):46-52. https://doi. org/10.1643/CI-08-187
- Bender A, Moritz T. Developmental residue and developmental novelty-different modes of adipose-fin formation during ontogeny. Zoosyst Evol. 2013; 89(2):209-14. https://doi. org/10.1002/zoos.201300007

- Boeseman M. The genus Hypostomus Lacepède, 1803, and its Surinam representatives (Siluriformes, loricariidae). Zoo Verhand. 1968; 99:1-89.

- Boeseman M. 2 Surinam species of Hypoptopomatinae, both new to science (Loricariidae, Siluriformes, Ostariophysi). P K Ned Akad C Biol. 1974; 77(3):257. 
- Britto MR, Moreira CR. Otocinclus tapirape: a new hypoptopomatine catfish from central Brazil (Siluriformes: Loricariidae). Copeia. 2002; 2002(4):106369. https://doi.org/10.1643/00458511(2002)002[1063:OTANHC]2.0.CO;2

- Carvalho TP, Lehmann AP, Pereira EHL, Reis RE. A new species of Hisonotus (Siluriformes: Loricariidae: Hypoptopomatinae) from the Laguna dos Patos basin, southern Brazil. Copeia. 2008; 2008(3):510-16. https://doi.org/10.1643/CI07-130

- Covain R, Fisch-Muller S, Oliveira C, Mol JH, Montoya-Burgos JI, Dray S. Molecular phylogeny of the highly diversified catfish subfamily Loricariinae (Siluriformes, Loricariidae) reveals incongruences with morphological classification. Mol Phylogenet Evol. 2016; 94:492-517. https:// doi.org/10.1016/j.ympev.2015.10.018

- Datovo A. A new species of Ituglanis from the Rio Xingu basin, Brazil, and the evolution of pelvic fin loss in trichomycterid catfishes (Teleostei: Siluriformes: Trichomycteridae). Zootaxa. 2014; 3790(3):466-76. https://10.11646/ zootaxa.3790.3.5

- Fernández L, Bichuette ME. A new cave dwelling species of Ituglanis from the São Domingos karst, central Brazil (Siluriformes: Trichomycteridae). Ichthyol Explor Fres. 2002; 13(3):273-78.

- Fernández L, Sanabria EA, Quiroga LB, Vari RP. A new species of Silvinichthys (Siluriformes, Trichomycteridae) lacking pelvic fins from mid-elevation localities of the southern Andes, with comments on the genus. J Fish Biol. 2014; 84(2):372-82. https://doi.org/10.1111/jfb.12291

- Fisch-Muller S, Cardoso AR, Silva JFD, Bertaco VA. Three new species of Ancistrus Kner (Teleostei: Siluriformes: Loricariidae) from the upper Tapajós and Tocantins rivers. Rev Suisse Zool. 2005; 112(2):559-72.

- Fowler HW. A collection of fresh-water fishes obtained in eastern Brazil by Dr. Rodolpho von Ihering. Pacad Nat Sci Phila. 1941; 93:123-336.

- Fricke R, Eschmeyer WN, editors. Guide to fish collections [Internet]. San Francisco: California Academy of Science; 2020. Available from: http://researcharchive. calacademy.org/research/ichthyology/ catalog/collections.asp
- Garstang W. A phyletic classification of Teleostei. Proc Leeds Philos Lit Soc, Sci Sect. 1931; 2:240-61.

- Gauger MFW, Buckup PA. Two new species of Hypoptopomatinae from the rio Paraíba do Sul basin, with comments on the monophyly of Parotocinclus and the Otothyrini (Siluriformes: Loricariidae). Neotrop Ichthyol. 2005; 3(4):509-18. http://dx.doi.org/10.1590/S167962252005000400008

- International Union for Conservation of Nature (IUCN). Standards and petitions subcommittee. Guidelines for using the IUCN Red List categories and criteria. Version 14 [Internet]. Gland; 2019. Available from: https://cmsdocs. s3.amazonaws.com/RedListGuidelines.pdf

- Lehmann AP, Lazzarotto H, Reis RE. Parotocinclus halbothi, a new species of small armored catfish (Loricariidae: Hypoptopomatinae), from the Trombetas and Marowijne River basins, in Brazil and Suriname. Neotrop Ichthyol. 2014; 12(1):27-33. http://dx.doi.org/10.1590/ S1679-62252014000100002

- Lehmann AP, Lima FCT, Reis RE. Parotocinclus yaka, a new species of armored catfish (Loricariidae: Hypoptopomatinae), from the Amazon basin in Brazil. Zootaxa. 2018; 4521(4):584-592. https://doi.org/10.11646/ zootaxa.4521.4.7

- Lehmann PA, Reis RE. A new species of Parotocinclus (Siluriformes: Loricariidae) from the upper Rio São Francisco, Brazil. Zootaxa. 2012; 3390(1):56-64. http://dx.doi. org/10.11646/zootaxa.3390.1.5

- Lehmann PA, Schvambach LJ, Reis RE. A new species of the armored catfish Parotocinclus (Loricariidae: Hypoptopomatinae), from the Amazon basin in Colombia. Neotrop Ichthyol. 2015; 13(1):47-52. http://dx.doi.org/10.1590/19820224-20140113

- Mattox GMT, Bichuette ME, Secutti S, Trajano E. Surface and subterranean ichthyofauna in the Serra do Ramalho karst area, northeastern Brazil, with updated lists of Brazilian troglobitic and troglophilic fishes. Biota Neotrop. 2008; 8(4):145-52. http://dx.doi.org/10.1590/ S1676-06032008000400014 
- Pereira EH, de A. Santos AC, de Pinna MC, Reis RE. An Enigmatic New Loricariid (Actinopterygii: Siluriformes) from Relictual Upper Reaches of Chapada Diamantina, Bahia, Brazil. Copeia. 2019; 107(4):597-605. https://doi.org/10.1643/CI-19-244

- Ramos TPA, Barros-Neto LF, Britski HA, Lima SM. Parotocinclus seridoensis, a new hypoptopomatine catfish (Siluriformes: Loricariidae) from the upper rio PiranhasAçu basin, northeastern Brazil. Neotrop Ichthyol. 2013; 11(4):787-96. http://dx.doi. org/10.1590/S1679-62252013000400006

- Ramos TPA, Lima SMQ, Ramos RTC. A new species of armored catfish Parotocinclus (Siluriformes: Loricariidae) from the rio Parnaíba basin, northeastern, Brazil. Neotrop Ichthyol. 2017; 15(2):e160153. http://dx.doi. org/10.1590/1982-0224-20160153

- Reimchen TE, Temple NF. Hydrodynamic and phylogenetic aspects of the adipose fin in fishes. Can J Zool. 2004; 82(6):910-16. https://doi.org/10.1139/z04-069

- Ribeiro AC, Carvalho M, Melo AL. Description and relationships of Otothyropsis marapoama, a new genus and species of Hypoptopomatine catfish (Siluriformes: Loricariidae) from rio Tietê basin, southeastern Brazil. Neotrop Ichthyol. 2005; 3(4):489-98. http://dx.doi. org/10.1590/S1679-62252005000400006

- Rosa AC, Martins FO, Langeani FDOM. Miniaturization in Otothyris Myers, 1927 (Loricariidae: Hypoptopomatinae). Neotrop Ichthyol. 2014; 12(1):53-60. http://dx.doi.org/10.1590/S167962252014000100005

- Roxo FF, Melo BF, Silva GSC, Oliveira C. New species of Parotocinclus (Siluriformes: Loricariidae) from coastal drainages of Rio de Janeiro, southeastern Brazil. Zootaxa. 2017; 4232(2):260-70. https://doi. org/10.11646/zootaxa.4232.2.9

- Roxo FF, Messias FL, Silva GS. A new species of Parotocinclus (Loricariidae: Hypoptopomatinae) from Rio Tocantins basin, Brazil. Zootaxa, 2019; 4646(2):346-56. http://dx.doi.org/10.11646/ zootaxa.4646.2.9

- Roxo FF, Silva GS, Oliveira C. Description of a new species of Parotocinclus (Siluriformes, Hypoptopomatinae) from the rio Tapajós basin. ZooKeys. 2016; 634:125-36. http://dx.doi.org/10.3897/ zookeys.634.9917
- Sandon H. An abnormal specimen of Synodontis membranaceus (Teleostei, Siluroidea), with a discussion on the evolutionary history of the adipose fin in fish. P Zool Soc Lond. 1956; 127(4):453-59. https:// doi.org/10.1111/j.1096-3642.1956.tb00481.x

- Schaefer SA. Osteology of Hypostomus plecostomus (Linnaeus) with phylogenetic analysis of the loricariid subfamilies (Pisces: Siluroidei). Nat His Mus Los Angel Cty. 1987; 394:1-31.

- Schaefer SA. A new species of the loricariid genus Parotocinclus from southern Venezuela (Pisces: Siluroidei). Copeia. 1988; 1988(1):182-88. https://doi. org/10.2307/1445936

- Schaefer SA. The Neotropical cascudinhos: systematics and biogeography of the Otocinclus catfishes (Siluriformes: Loricariidae). P Acad Nat Sci Phila. 1997; 148:1-120.

- Schaefer SA, Provenzano F. The Guyana Shield Parotocinclus: systematics, biogeography, and description of a new Venezuelan species (Siluroidei: Loricariidae). Ichthyol Explor Fresh. 1993; 4(1):39-56.

- Schmidt RE, Ferraris Jr CJ. A new species of Parotocinclus (Pisces: Loricariidae) from Guyana. P Biol Soc Wash. 1985; 98(2):34146.

- Secutti S, Trajano E. Reproductive behavior, development and eye regression in the cave armored catfish, Ancistrus cryptophthalmus Reis, 1987 (Siluriformes: Loricariidae), breed in laboratory. Neotrop Ichthyol. 2009; 7(3):479-90. http://dx.doi. org/10.1590/S1679-62252009000300016

- Stewart TA, Hale ME. First description of a musculoskeletal linkage in an adipose fin: innovations for active control in a primitively passive appendage. Proc Biol Sci 2013; 280(1750):20122159. https://doi. org/10.1098/rspb.2012.2159

- Stewart TA, Smith WL, Coates MI. The origins of adipose fins: an analysis of homoplasy and the serial homology of vertebrate appendages. Proc Biol Sci. 2014; 281(1781):20133120. https://doi. org/10.1098/rspb.2013.3120

- Taylor WR, Van Dyke GC. Revised procedures for staining and clearing small fishes and other vertebrates for bone and cartilage study. Cybium. 1985; 9(2):107-20. 


\section{Neotropical Ichthyology}

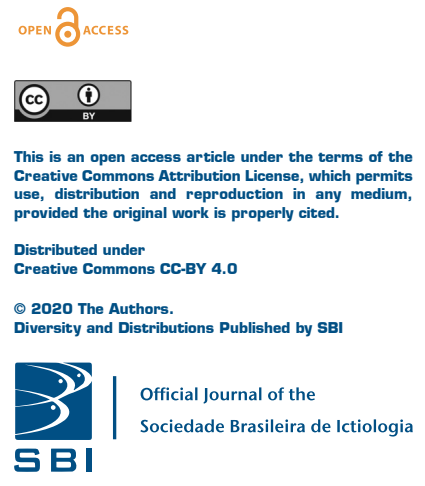

- Temple NF, Reimchen TE. Adipose fin condition and flow regime in catfish. Can J Zool. 2008; 86(9):1079-82. https://doi. org/10.1139/Z08-086

\section{AUTHOR'S CONTRIBUTION ↔}

Dario Silva-Junior: Conceptualization, Formal analysis, Writing-original draft, Writing-review \& editing.

Telton P. A. Ramos: Methodology, Validation, Writing-review \& editing.

Angela M. Zanata: Formal analysis, Funding acquisition, Investigation, Project administration, Writing-review \& editing.

\section{ETHICAL STATEMENT}

Not applicable.

\section{COMPETING INTERESTS}

The authors declare no competing interests.

\section{HOW TO CITE THIS ARTICLE}

- Silva-Junior DE, Ramos TP, Zanata AM. A new species of Parotocinclus with reduced adipose fin (Loricariidae: Hypoptopomatinae), from the rio Jacuípe basin, Bahia State, Brazil. Neotrop Ichthyol. 2020; 18(2):e190137. https://doi.org/10.1590/1982-0224-2019-0137 